\title{
Identified Of Indicator And Material For Product Shelf Life Recorder Smart Label
}

\author{
Endang Warsiki ${ }^{1 *}$ dan Riris Octaviasari ${ }^{1}$ \\ ${ }^{1}$ Departemen Teknologi Industri Pertanian, Fakultas Teknologi Pertanian, Institut Pertanian Bogor \\ Kampus IPB Darmaga, Kotak POS 122, Bogor 16002 \\ *Email : endangwarsiki@qpps.ipb.ac.id
}

\begin{abstract}
Shelf life is an important factor in determining the quality and safety of food for consumption. Refrigerator becomes an alternative in extending product shelf life. Shelf life is difficult to be identified if the product stored for too long. Smart label of Time Temperature Indicators (TTI) can record the product shelf life based on its storage time. In this research, identification of indicator and material for smart label development based on liquid diffusion in material was conducted. This study used several types of materials (Buffalo paper, HVS $80 \mathrm{gr}$, photo paper, concord, drawing paper and cardboard duplex), low viscosity indicators (board-marker ink, stamp, tubs, permanent tattoo and non-permanent tattoos) and high viscosity indicators (cooking oil, lubricant A and lubricant B). The initial phase was characterizations such as grammage, density, mass density and viscosity test aimed to determine the properties of indicators and materials. Identification was implemented by measuring the diffusion length of indicator in the material at 24, 48, 72 and $96 \mathrm{~h}$ in temperature of $30.15^{\circ} \mathrm{C}$ and $50^{\circ} \mathrm{C}$ for cooking oil, while $30.15^{\circ} \mathrm{C}$ and $5^{\circ} \mathrm{C}$ for oil $A$ and $B$. The slope of diffusion length versus time is called by rate constant ( $k$ ), where as the slope of ln $k$ versus 1/T is called by activation energy (Ea). Best indicator and the material were selected based on their high value of Ea. Result showed that the ink was not be absorbed during storage due to its high volatility and low viscosity, while cooking oil, lubricant $A$ and lubricant $B$ have specific diffusion length during storage. These indicators and mediums were able to detect up to 4 days of shelf life during storage. Based on activation energy, the most suitable indicator for smart label was lubricant A. The best materials for this label development sequentially from low-to-high activation energy were Buffalo paper, duplex cartons, drawing paper, concord, HVS $80 \mathrm{~g}$ and photo paper.
\end{abstract}

Keyword: color indicator, diffusion, shelf life recorder 


\section{PENDAHULUAN}

Umur simpan merupakan rentang waktu antara saat produk mulai dikemas dengan mutu produk yang masih memenuhi syarat dikonsumsi. Informasi mengenai umur simpan produk sangat penting untuk dicantumkan karena berhubungan erat dengan kualitas dan keamanan produk pangan. Salah satu alternatif yang dilakukan untuk mengetahui masa penyimpanan produk yaitu dengan membuat label cerdas yang dapat mencatat umur simpan produk yang dikenal dengan TimeTemperature Indicator (TTI). Salah satu prinsip pembuatan TTI yaitu dengan memanfaatkan prinsip difusi suatu indikator pada medium tertentu.

Pada penelitian ini akan dilakukan identifikasi medium dan indikator yang sesuai untuk pembuatan label cerdas. Kertas dan karton dipilih sebagai bahan medium peresapan karena memiliki pori-pori antar ikatan serat selulosa yang dapat dilewati cairan. Indikator menggunakan dua jenis zat cair viskositas berbeda, yaitu viskositas rendah dan viskositas tinggi. Laju difusi dipengaruhi oleh viskositas, dimana semakin tinggi viskositas cairan akan semakin tinggi laju alirnya dan sebaliknya. Pada dasarnya label akan diaplikasikan pada pencatatan umur simpan produk yang disimpan di lemari es, sehingga zat cair akan dipilih berdasarkan daya resap paling rendah rendah karena untuk memudahkan dalam pembuatan dan aplikasi label.

Label cerdas akan dibuat dengan menggunakan prinsip difusi zat cair, dimana indikator zat cair akan dibiarkan meresap (difusi) pada kertas selama kurun waktu 4 hari penyimpanan dengan memanfaatkan panjang peresapan sebagai pencatat lamanya penyimpanan produk dalam lemari es pada hari ke-1, 2, 3 dan 4. Label akan mencatat masa penyimpanan produk yang berbasis pada daya peresapan zat cair (difusi). Semakin lama proses penyimpanan, maka akan semakin panjang pula peresapan zat cair pada media. Oleh karena itu perlu dilakukan kajian lebih lanjut terkait jenis zat cair dan medium yang digunakan sebagai media peresapan agar dihasilkan label cerdas yang dapat mencatat umur simpan produk.

\section{TINJAUAN PUSTAKA}

\section{A. Kemasan Cerdas}

Kemasan cerdas (smart packaging) adalah kemasan yang memiliki indikator baik yang diletakkan secara internal maupun secara eksternal dan mampu memberikan informasi tentang keadaan kemasan dan atau kualitas kemasan di dalamnya (Robertson 2006). Pengemasan cerdas bertujuan untuk mengawasi kondisi makanan terkemas sewaktu transportasi dan penyimpanan. Pengawasan kondisi makanan dilakukan dengan menggunakan indikator yang dibedakan atas indikator luar dan indikator dalam.

\section{B. Time-Temperature Indicator (TTI)}

Salah satu solusi kemasan cerdas indikator suhu-waktu yang tersedia untuk dapat mendeteksi umur simpan produk non-destruktif yaitu TimeTemperature Indicator (TTI). Time-Temperature Indicator (TTI) didefinisikan sebagai sebuah perangkat atau alat yang digunakan untuk menentukan ukuran perubahan suhu dan waktu yang terjadi dengan mencerminkan pengukuran suhu secara keseluruhan maupun suhu parsial produk makanan yang disimpan dalam jangka waktu tertentu (Taoukis dan Labuza 1989). Ada dua tipe Time Temperature Indicator yaitu memberikan perubahan suhu yang masuk untuk menunjukkan kumulatif dari perubahan suhu diatas suhu kritis serta lamanya perubahan suhu itu terjadi (Time Temperature Indicators-TTI) dan memberikan informasi apakah suhu berada diatas atau dibawah suhu kritis (Temperature indicatorsTI).

\section{Difusi}

Difusi atau pembauran (Diffusion) merupakan gerakan suatu komponen melalui suatu campuran yang berlangsung karena suatu rangsangan fisika. Pada umumnya, peristiwa difusi disebabkan oleh adanya gradien atau (landaian) konsentrasi pada komponen yang terdisfusi itu (McCabe et al 1999). Menurut Adrimarsya (2012) beberapa faktor yang mempengaruhi kecepatan difusi, yaitu:

1. Ukuran partikel, Semakin kecil ukuran partikel, semakin cepat partikel itu akan bergerak, sehinggak kecepatan difusi semakin tinggi.

2. Ketebalan membran. Semakin tebal membran, semakin lambat kecepatan difusi.

3. Luas suatu area. Semakin besar luas area, semakin cepat kecepatan difusinya.

4. Jarak. Semakin besar jarak antara dua konsentrasi, semakin lambat kecepatan difusinya.

5. Suhu. Semakin tinggi suhu, partikel mendapatkan energi untuk bergerak dengan lebih cepat. Maka, semakin cepat pula kecepatan difusinya.

\section{Potensi Pemanfaatan Indikator dan Medium}

Label cerdas pencatat umur simpan produk dapat dibuat dengan menggunakan prinsip difusi. Medium vano diounakan untuk media nerecanan 
merupakan material yang dibuat dari bahan dasar yang mengandung selulosa yang diberi perlakuan kimia, dibilas, diuraikan, dipucatkan, dibentuk menjadi lembaran setelah pressing dan dikeringkan (Sinuhaji 2010).

Indikator yang digunakan yaitu zat cair. Dua jenis indikator yang digunakan berdasarkan perbedaan viskositas yaitu viskositas rendah berupa tinta dan viskositas tinggi berupa minyak (Kanoni 1999). Tinta mengandung tiga komponen utama yang terdiri dari bahan pewarna (pigmen), zat pengikat (varnish/vehicle), dan zat aditif atau bahan penolong. Adanya bahan pewarna pada tinta dapat memudahkan dalam melihat respon difusi zat cair pada medium selama masa penyimpanan untuk mencatat umur simpan. Selain itu tinta memiliki komponen yang dapat mempengaruhi tingkat viskositas seperti pelarut (Hidrokarbon, ester, keton dan alkohol).

Zat cair yang memiliki viskositas tinggi yaitu minyak. Jenis minyak yang memiliki viskositas tinggi seperti minyak goreng dan oli. Minyak kelapa sawit yang menjadi bahan baku minyak goreng memiliki viskositas sebesar $60 \mathrm{cSt}$ pada suhu $20^{\circ} \mathrm{C}$ (Vaitilingom et al. 1997), sedangkan oli memiliki viskositas sebesar 39.30 cSt (Nugroho dan Sunarno 2012). Adanya perbedaan viskositas, dapat digunakan sebagai perbandingan indikator viskositas tinggi dalam pembuatan label cerdas dengan mengetahui panjang peresapan masing-masing indikator pada medium.

\section{Tetapan Laju dan Energi Aktivasi}

Daya serap dari zat cair pada media digambarkan dengan panjang peresapan zat cair mengikuti persamaan kinetika orde satu (Coe 1971; Smith 1993; Ritchie 1996 dalam Warsiki 2006) sebagai berikut:

$$
-\frac{\partial \mathrm{C}}{\partial \mathrm{t}}=\mathrm{k}\left(\mathrm{C}_{\sim}-\mathrm{C}_{\mathrm{t}}\right)
$$

dimana $\mathrm{C}$ adalah konsentrasi pelarut; $\mathrm{k}$ adalah konstanta orde satu; $\mathrm{C}_{\sim}$ dan $\mathrm{Ct}$ menunjukkan konsentrasi pada saat keseimbangan, dan $\mathrm{t}$ adalah waktu. Dari persamaan (1) maka variabel yang digunakan untuk menentukan konstanta daya serap zat cair pada medium sebagai berikut:

$$
-\frac{\partial \mathrm{L}}{\partial \mathrm{t}}=\mathrm{k}\left(\mathrm{L}_{\sim}-\mathrm{Lt}\right)
$$

sehingga:

$$
\begin{aligned}
& \frac{\partial \mathrm{L}}{\partial \mathrm{t}}=\mathrm{k} \Delta \mathrm{L} \\
& \text { dimana : } \mathrm{L}=\text { panjang serapan }(\mathrm{cm}) \\
& \mathrm{k}=\text { konstanta serapan } \\
& \mathrm{r}+\ldots . . . \mathrm{inn} \text {-1.1... }
\end{aligned}
$$

$$
\mathrm{L}_{\sim}=\underset{\text { panjang awal serapan saat }}{\text { penyimpanan jam tak terhingga }}
$$

Berdasarkan persamaan (2) hubungan antara nilai $\mathrm{k}$ dengan perubahan panjang peresapan dapat dituliskan pada persamaan 4 dengan penjabaran dapat dilihat pada Lampiran 1.

$$
\mathrm{kt}=\ln \left[\mathrm{L}_{\sim} /\left(\mathrm{L}_{\sim}-\mathrm{Lt}\right)\right]
$$

Dengan demikian konstanta laju serapan $\mathrm{k}$ dapat diperoleh dari slope grafik hubungan antara nilai $\ln \left[\mathrm{L}_{\sim} /\left(\mathrm{L}_{\sim}-\mathrm{Lt}\right)\right]$ terhadap waktu $(\mathrm{t})$.

Tetapan laju sangat tergantung suhu. Hubungan antara logaritma dari tetapan laju dan kebalikan dari suhu mutlak pada kisaran tertentu dari suhu secara linier dan kuantitatif dijelaskan dengan menggunakan persamaan Arrhenius (Smith 1993; Coe 1971 dalam Warsiki 2006). Persamaan Arrhenius tersebut menunjukkan hubungan antara tetapan laju k, suhu dan energi aktivasi.

$$
\mathrm{k}=\mathrm{A} \times e^{-\mathrm{Ea} / \mathrm{RT}}
$$

Dimana, $\mathrm{k}=$ tetapan laju

$$
\begin{aligned}
& \mathrm{A}=\text { faktor frekuensi } \\
& \mathrm{Ea}=\text { energi aktivasi }(\mathrm{J} / \mathrm{mol}) \\
& \mathrm{R}=\text { tetapan gas ideal }=8.3184 \mathrm{~J} / \mathrm{mol} \mathrm{K} \\
& \mathrm{T}=\operatorname{suhu} \text { mutlak }(\mathrm{K})
\end{aligned}
$$

dengan demikian energi aktivasi (Ea) dan faktor frekuensi (A) dapat diketahui dari nilai slope dan intersep dari grafik plot nilai hubungan antara $\mathrm{ln} \mathrm{k}$ dengan $1 / \mathrm{T}$ (persamaan 6).

$\ln \mathrm{k}=-\mathrm{Ea} / \mathrm{RT}+\ln \mathrm{A}$

\section{METODE PENELITIAN}

\section{A. Alat dan Bahan}

1. Alat

Alat yang digunakan dalam penelitian ini adalah gunting, bolpoin, penggaris, lemari es, jar, gelas ukur, thickness gauge, tabung Ostwald, piknometer, waterbath, gelas piala, neraca analitik, sudip, inkubator, termometer ruangan dan pipet tetes.

2. Bahan

Bahan utama yang digunakan dalam penelitian ini adalah lima jenis kertas dan satu jenis karton yaitu buffalo, HVS $80 \mathrm{~g}$, foto, concord, buku gambar dan karton duplex sebagai medium pembuatan label, 5 jenis tinta yaitu tinta tato permanen, tinta tato non permanen, tinta spidol boardmarker, tinta bak, dan tinta stempel, minyak goreng, oli A, oli B, sebagai zat cair yang digunakan, pewarna minyak dan alkohol. 
$B$.

C.

\section{Prosedur Penelitian}

\section{1) Karakterisasi Medium}

\section{Uji Gramatur (SNI 0123:2008)}

Prosedur percobaan yang dilakukan untuk menghitung nilai gramatur kertas atau karton yaitu lembaran kertas atau karton dipotong dengan ukuran sampel $20 \times 1.5 \mathrm{~cm}$. Kemudian potongan sampel ditimbang untuk menentukan massa kertas atau karton. Setiap sampel tersebut diukur panjang dan lebarnya untuk menentukan luas. Gramatur diperoleh dari perhitungan menggunakan rumus nilai gramatur (persamaan 7).

$$
\mathrm{G}=\frac{\mathrm{m}}{\mathrm{L}}
$$

Dimana:

$$
\begin{aligned}
& \mathrm{G}=\text { Gramatur kertas atau karton }\left(\mathrm{g} / \mathrm{m}^{2}\right) \\
& \mathrm{m}=\text { Massa kertas atau karton }(\mathrm{g}) \\
& \mathrm{L}=\text { Luas kertas atau karton }\left(\mathrm{m}^{2}\right)
\end{aligned}
$$

\section{Uji Rapat Massa (SNI 0123:2008)}

Prosedur percobaan yang dilakukan untuk menghitung nilai rapat massa yaitu lembaran kertas atau karton dipotong sesuai ukuran sampel $20 \times 1.5$ $\mathrm{cm}$. Kemudian ditimbang untuk menentukan massa masing-masing kertas atau karton. Setiap kertas atau karton diukur panjang dan lebarnya untuk menentukan luas. Selanjutnya kertas atau karton juga diukur nilai ketebalannya. Rapat massa diperoleh dari perhitungan menggunakan rumus nilai rapat massa (persamaan 8 ).

$$
\text { Rapat Massa }\left(\mathrm{kg} / \mathrm{m}^{3}\right)=\frac{\text { Massa Sampel }(\mathrm{kg})}{\operatorname{Volume} \text { Sampel }\left(\mathrm{m}^{3}\right)}
$$

\section{2) Karakterisasi Zat Cair}

\section{Uji Densitas (SNI 04-7182-2006)}

Piknometer kosong dicuci dengan aquades dan dibilas dengan etanol, ditimbang lalu diisi dengan air dan dimasukkan ke dalam penangas air yang telah ditetapkan suhunya, yaitu $25^{\circ} \mathrm{C}$. Kemudian permukaan air diatur sampai pada puncak kapiler, dibiarkan selama 15 menit. Piknometer dipindahkan dari penangas, dikeringkan bagian luarnya dan ditimbang dengan teliti. Piknometer dikosongkan, lalu dibasuh beberapa kali dengan alkohol kemudian dikeringkan kembali. Prosedur di atas diulangi dengan menggunakan sampel yang akan diukur sebagai pengganti air. Densitas sampel dapat diukur dengan rumus berikut
Bobot jenis sampel pada suhu tertentu dapat dihitung dengan rumus, $\mathrm{G}=\mathrm{G}^{\prime}+$ nilai koreksi $\left(25^{\circ} \mathrm{C}-\mathrm{T}^{\circ} \mathrm{C}\right)$. Nilai koreksi ditambahkan jika pengukuran di atas suhu $15^{\circ} \mathrm{C}$, dan dikurangi pada suhu di bawah $15^{\circ} \mathrm{C}$.

Dimana:

$\mathrm{G}=$ bobot jenis sampel pada suhu $25^{\circ} \mathrm{C}$

$\mathrm{G}^{\prime}=$ bobot jenis sampel pada suhu pengukuran (pada $\mathrm{T}^{\circ} \mathrm{C}$ ).

\section{Uji Viskositas (SNI 04-7182-2006)}

Analisis ini dilakukan dengan menggunakan alat viskosimeter. Aquades dipanaskan pada suhu $40^{\circ} \mathrm{C}$ dan dimasukkan ke dalam tabung viskosimeter Ostwald. Waktu yang diperlukan untuk mencapai tanda tera dicatat. Selanjutnya zat cair dipanaskan pada suhu $40^{\circ} \mathrm{C}$ dan dimasukkan ke dalam tabung viskosimeter Ostwald. Kemudian waktu yang diperlukan untuk mencapai tanda tera dicatat. Viskositas diperoleh dari perhitungan menggunakan rumus nilai viskositas (persamaan 9).

$$
\text { Viskositas }=\mu \times \frac{\mathrm{d} 2 \times \mathrm{t} 2}{\mathrm{~d} 1 \times \mathrm{t} 1}
$$

Dimana:

$$
\begin{aligned}
& \mu \quad=\text { viskositas aquades suhu } 40^{\circ} \mathrm{C} \\
& \mathrm{d} 1=\text { densitas aquades suhu } 40^{\circ} \mathrm{C}(\mathrm{g} / \mathrm{mL}) \\
& \text { t1 = waktu yang diperlukan aquades untuk }
\end{aligned}
$$

\section{3) Pemilihan Kesesuaian Jenis Cairan dan Medium}

Medium peresapan yang digunakan terdiri dari buffalo, HVS $80 \mathrm{~g}$, foto, concord, gambar dan karton duplex. Zat cair sebagai indikator peresapan pada medium dipilih dari dua cairan yang berbeda. Dua jenis cair yang digunakan dipilih berdasarkan perbedaan viskositas yaitu viskositas tinggi meliputi minyak goreng, oli A dan oli B dan viskositas rendah meliputi tinta tato permanen, tinta tato non permanen, tinta spidol boardmarker, tinta bak, dan tinta stempel

\section{Pembuatan Label dengan Indikator Viskositas Rendah}

Kertas atau karton dipotong persegi panjang (label) dengan ukuran $20 \times 1.5 \mathrm{~cm}$, kemudian tinta diteteskan di salah satu ujung kertas atau karton. Selanjutnya didiamkan selama 10 detik dan diberi tanda pada batas penyebaran setelah tinta diteteskan sebagai batas pengamatan pada jam ke0 . Selanjutnya label disimpan pada suhu ruang selama 96 jam dengan melakukan pencatatan 


\section{4) Pembuatan Label dengan Indikator Viskositas Tinggi \\ Kertas atau karton dipotong persegi panjang} dengan ukuran $20 \times 1.5 \mathrm{~cm}$ kemudian dicelupkan ke dalam jar berisi zat cair yang telah diberikan pewarna sebelumnya. Kertas atau karton diberi tanda pada bagian ujungnya untuk memudahkan pengukuran pengamatan jam ke-0. Selanjutnya label disimpan pada suhu ruang selama 96 jam dengan melakukan pencatatan panjang peresapan zat cair dicatat pda jam ke-24,48,72 dan 96.

\section{HASIL DAN PEMBAHASAN}

\section{A. Karakterisasi Medium}

\section{1) Gramatur}

Gramatur adalah massa lembaran kertas atau karton dalam g dibagi dengan satuan luas kertas atau karton dalam meter persegi, diukur pada kondisi standar (BSN 2008). Nilai gramatur dari jenis dan komposisi bahan (pulp) dalam proses pembuatannya. Berdasarkan perhitungan gramatur yang dilakukan, maka nilai gramatur setiap kertas atau karton yang digunakan dapat dilihat pada Gambar 5.

Dari Gambar 5 menunjukkan hubungan jenis kertas atau karton dengan nilai gramaturnya. Berdasarkan Gambar 5 dapat dilihat bahwa nilai gramatur kertas buffalo, HVS $80 \mathrm{~g}$, foto, Concord, gambar dan karton duplex yaitu $152.222 \mathrm{~g} / \mathrm{m}^{2}$, $85.556 \mathrm{~g} / \mathrm{m}^{2}, 235.556 \mathrm{~g} / \mathrm{m}^{2}, 231.111 \mathrm{~g} / \mathrm{m}^{2}, 151.111$ $\mathrm{g} / \mathrm{m}^{2}$, dan $1055.556 \mathrm{~g} / \mathrm{m}^{2}$.

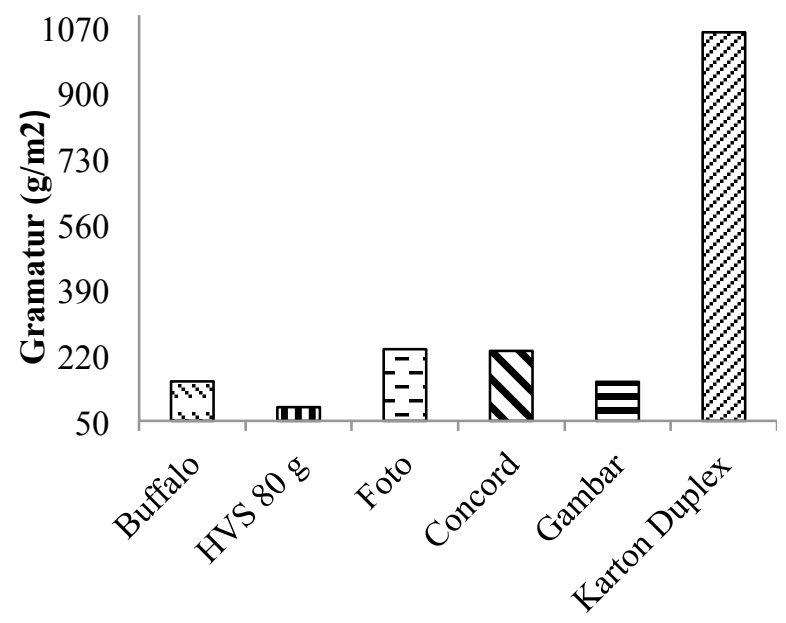

Jenis Medium

Gambar 5 Grafik hubungan jenis medium dengan nilai gramatur

\section{2) Rapat Massa}

Rapat massa adalah massa lembaran karton dalam kilogram dibagi dengan satuan volume standar (BSN 2008). Berdasarkan perhitungan rapat massa yang dilakukan, maka nilai rapat masing-masing medium yang digunakan dapat dilihat pada Gambar 6.

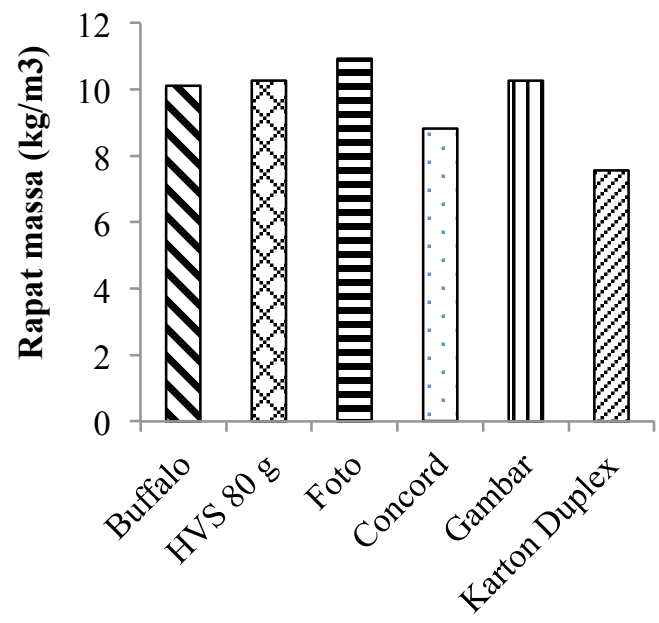

Jenis medium

Gambar 6 Grafik hubungan jenis medium dengan nilai rapat massa

Berdasarkan Gambar 6 dapat dilihat bahwa nilai rapat massa dari kertas buffalo, HVS $80 \mathrm{~g}$, foto, concord, gambar dan karton duplex secara berturut-turut yaitu $10.111 \mathrm{~kg} / \mathrm{m}^{3}, 10.267 \mathrm{~kg} / \mathrm{m}^{3}$, $10.928 \mathrm{~kg} / \mathrm{m}^{3}, 8.832 \mathrm{~kg} / \mathrm{m}^{3}, 10.264 \mathrm{~kg} / \mathrm{m}^{3}$, dan $7.561 \mathrm{~kg} / \mathrm{m}^{3}$. Secara teknis rapat massa mempunyai hubungan erat dengan daya ikatan antar seratnya (Casey 1961 dalam Nurminah 2002).

\section{B. Karakterisasi Zat Cair \\ C. Densitas}

Densitas merupakan hasil pengukuran massa setiap satuan volume benda atau zat. Uji densitas hanya dilakukan pada zat cair viskositas tinggi yaitu minyak goreng, oli A dan oli B karena tingkat volatilitas tinta yang sangat tinggi sehingga tidak dapat dilakukan uji densitas. Hubungan perubahan densitas dan suhu pada minyak goreng, oli A dan oli B tersebut dapat dilihat pada Gambar 7.

Gambar 7 menunjukkan kecenderungan penurunan nilai densitas terhadap peningkatan suhu. Pada suhu $25^{\circ} \mathrm{C}$ untuk minyak goreng, oli A dan Oli B mempunyai nilai densitas sebesar 0.910 $\mathrm{g} / \mathrm{mL}, 0.818 \mathrm{~g} / \mathrm{mL}$ dan $0.804 \mathrm{~g} / \mathrm{mL}$. Pada suhu $40^{\circ} \mathrm{C}$ nilai densitas minyak goreng, oli $\mathrm{A}$ dan oli $\mathrm{B}$ yaitu $0.907 \mathrm{~g} / \mathrm{mL}, 0.817 \mathrm{~g} / \mathrm{mL}$ dan $0.803 \mathrm{~g} / \mathrm{mL}$, sedangkan nilai densitas pada suhu $50^{\circ} \mathrm{C}$ untuk minyak goreng, oli A dan oli B yaitu $0.906 \mathrm{~g} / \mathrm{mL}$, $0.810 \mathrm{~g} / \mathrm{mL}, 0.802 \mathrm{~g} / \mathrm{mL}$. 


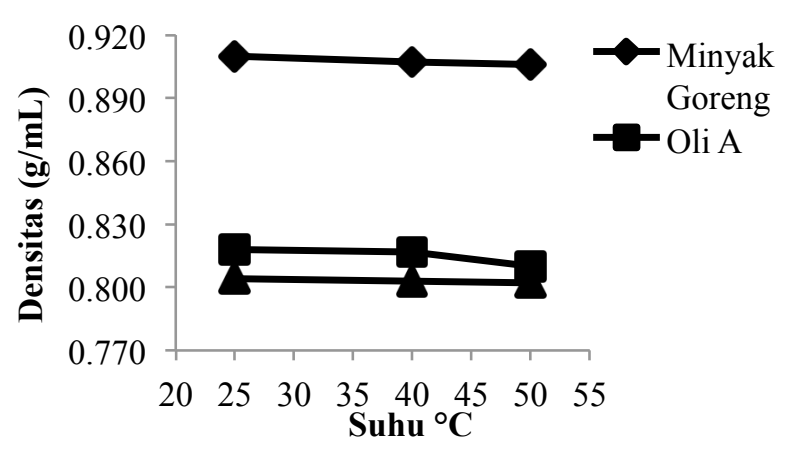

Gambar 7 Grafik hubungan antara densitas dan suhu pada minyak goreng, oli A dan oli B

Berdasarkan Gambar 7, maka dapat diperoleh nilai laju penurunan densitas minyak goreng, oli A dan oli B secara berturutan yaitu $0.0002 \mathrm{~g} / \mathrm{mL}$ per jam, $0.0003 \mathrm{~g} / \mathrm{mL}$ per jam dan $0.0001 \mathrm{~g} / \mathrm{mL}$ per jam. Beberapa minyak nabati yang telah diteliti menunjukkan kecenderungan penurunan densitas secara linier terhadap peningkatan suhu. Penurunan densitas disebabkan telah terjadinya peningkatan volume CPO dengan massa konstan pada suhu yang tinggi (Noureddini et al 1992 dalam Permatasari 2011). Adanya peningkatan volume ini disebabkan oleh pecahnya molekul-molekul minyak akibat pengaruh suhu yang tinggi sehingga molekul-molekul menempati volume yang lebih besar dibandingkan saat suhu rendah (Cuah et al. 2008 dalam Permatasari 2011).

1)

2) Viskositas

Viskositas merupakan resistensi atau ketidakmauan bahan mengalir apabila dikenai gaya (mengalami penegangan) atau gesekan internal dalam cairan. Semakin lambat aliran berarti viskositasnya tinggi, dan sebaliknya semakin cepat aliran berarti viskositasnya makin rendah (Kanoni 1999). Uji viskositas juga hanya dilakukan pada zat cair viskositas tinggi yaitu minyak goreng, oli A dan oli B karena tingkat volatilitas tinta yang tinggi sehingga tidak dapat dilakukan uji viskositas. Perbedaan tingkat viskositas antara oli A dan oli B dapat dilihat pada Tabel 1.

Tabel 1 Perbedaan viskositas minyak goreng,

\begin{tabular}{llll}
\multicolumn{3}{c}{ oli A dan oli B } & \\
\hline Jenis zat cair & $\begin{array}{l}\text { Viskositas } \\
\text { (cSt) }\end{array}$ & pada & $\mathbf{4 0}^{\circ} \mathbf{C}$ \\
& 23.365 & \\
Minyak goreng & 56.491 & \\
Oli A & 51.835 & \\
Oli B & & \\
\hline
\end{tabular}

Berdasarkan Tabel 1 dengan pengukuran viskositas minyak goreng dan oli pada suhu $40^{\circ} \mathrm{C}$ telah terjadi penurunan viskositasnya. Semakin kental nelumas maka akan semakin herat hohotnva ketika panas, dan menjadi kental dan tidak mudah mengalir ketika dingin (Soedarmo 2008). Semakin tinggi nilai viskositas cairan, maka akan semakin baik pula dalam penggunaan cairan sebagai indikator dalam pembuatan label cerdas.

\section{Pemilihan Kesesuaian Jenis Cairan dan Kertas}

Label cerdas digunakan untuk mengetahui umur simpan produk selama 4 hari penyimpanan dalam lemari es. Zat cair yang digunakan sebagai indikator berdasarkan viskositas yaitu viskositas tinggi dan viskositas rendah. Medium peresapan yang digunakan yaitu kertas atau karton. Penelitian yang menggunakan tinta sebagai indikator menunjukkan hasil yang tidak sesuai antara jenis zat cair dan medium yang digunakan. Tinta hanya mampu meresap pada jam ke-1. Setelah itu tinta mengering dan tidak dapat meresap karena tinta yang ada di pasaran umumnya mempunyai tingkat volatilitas yang tinggi dan viskositas rendah sehingga tinta akan lebih cepat mengering.

Penelitian yang menggunakan zat cair dengan viskositas tinggi menunjukkan hasil yang sesuai dengan prinsip difusi zat cair pada medium untuk mencatat umur simpan selama 4 hari penyimpanan. Berdasarkan penelitian yang dilakukan, rata-rata panjang peresapan minyak goreng, oli A dan oli B pada setiap medium yang digunakan dari jam ke-24 sampai jam ke-96 pada suhu ruang $\left(30.15^{\circ} \mathrm{C}\right)$ dapat dilihat pada Gambar 8 , Gambar 9 dan Gambar 10.

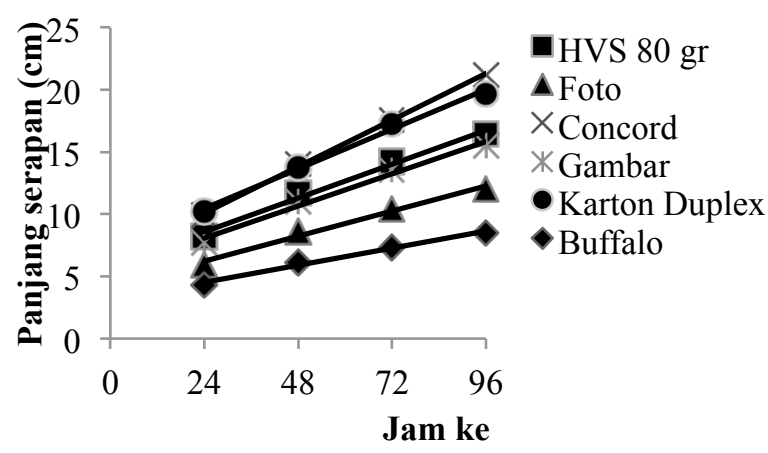

Gambar 8 Grafik hubungan panjang serapan minyak goreng pada medium

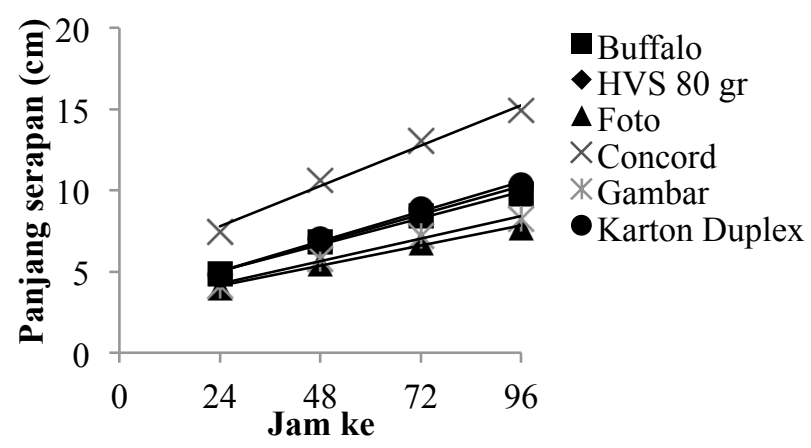


Gambar 9 Grafik hubungan panjang serapan oli A pada medium

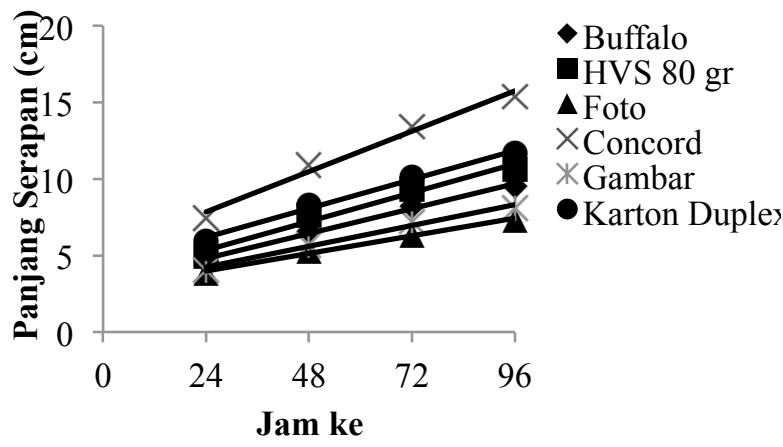

Gambar 10 Grafik hubungan panjang serapan oli B pada medium

Berdasarkan Gambar 6, Gambar 7 dan Gambar 8 dapat dipilih tiga jenis medium dan indikator paling baik yaitu kertas buffalo, foto dan gambar dengan indikator berupa oli berdasarkan pertimbangan panjang label yang akan dibuat. Panjang peresapan indikator minyak goreng pada semua medium yang digunakan mencapai lebih dari $15 \mathrm{~cm}$. Label yang dibuat dengan panjang lebih dari $15 \mathrm{~cm}$ akan menyulitkan aplikasi label. Berdasarkan Gambar 6, Gambar 7 dan Gambar 8 maka laju serapan dan nilai $\mathrm{R}^{2}$ zat cair pada medium (cm/jam) dapat dilihat pada Tabel 2.

Tabel 2 Laju serapan dan $\mathrm{R}^{2}$ zat cair pada kertas

\begin{tabular}{|c|c|c|c|}
\hline $\begin{array}{l}\text { Jenis Zat } \\
\text { Cair }\end{array}$ & Jenis Kertas & $\begin{array}{l}\text { Laju } \\
\text { Serapan } \\
\text { (cm/jam) }\end{array}$ & $\mathbf{R}^{2}$ \\
\hline \multirow{7}{*}{$\begin{array}{l}\text { Minyak } \\
\text { Goreng }\end{array}$} & Buffalo & 0.0573 & 0.9890 \\
\hline & HVS $80 \mathrm{~g}$ & 0.1133 & 0.9889 \\
\hline & Foto & 0.0840 & 0.9853 \\
\hline & Concord & 0.1560 & 0.9986 \\
\hline & Gambar & 0.1079 & 0.9868 \\
\hline & Karton & & \\
\hline & Duplex & 0.1330 & 0.9930 \\
\hline \multirow{7}{*}{ Oli A } & Buffalo & 0.0680 & 0.9935 \\
\hline & HVS $80 \mathrm{~g}$ & 0.0730 & 0.9862 \\
\hline & Foto & 0.0517 & 0.9897 \\
\hline & Concord & 0.1035 & 0.9867 \\
\hline & Gambar & 0.0579 & 0.9896 \\
\hline & Karton & 0.0766 & 0.9917 \\
\hline & Duplex & & \\
\hline \multirow{7}{*}{ Oli B } & Buffalo & 0.0678 & 0.9895 \\
\hline & HVS $80 \mathrm{~g}$ & 0.0783 & 0.9733 \\
\hline & Foto & 0.0479 & 0.9910 \\
\hline & Concord & 0.1098 & 0.9841 \\
\hline & Gambar & 0.0566 & 0.9832 \\
\hline & Karton & & \\
\hline & Duplex & 0.0788 & 0.9909 \\
\hline
\end{tabular}

E.

\section{F. Tetapan Laju Serapan dan Energi Aktivasi}

Energi aktivasi antara setiap medium dan zat cair dapat diketahui dari nilai slope plot nilai panjang peresapan yang dilakukan pada kondisi suhu yang berbeda. Suhu yang digunakan untuk pengujian yaitu suhu ruang $\left(30.15^{\circ} \mathrm{C}\right)$ dan suhu lemari es $\left(5^{\circ} \mathrm{C}\right)$. Pada pengujian jam ke-24, indikator oli dapat meresap, sedangkan minyak goreng tidak dapat meresap karena memiliki titik beku yang lebih rendah dibandingkan oli. Sehingga untuk menentukan nilai aktivasi minyak goreng dilakukan pada suhu yang lebih tinggi. Berdasarkan hasil penelitian, hubungan panjang peresapan terhadap waktu pada indikator minyak goreng, oli A dan oli B pada setiap jenis medium pada suhu $30.15^{\circ} \mathrm{C}$ dapat dilihat pada Gambar 13, Gambar 14 dan Gambar 15.

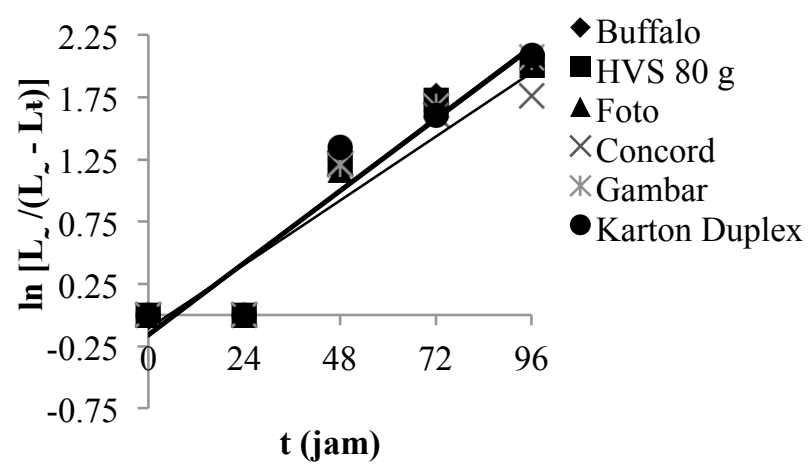

Gambar 13 Grafik hubungan antara $\ln \left[\mathrm{L} /\left(\mathrm{L}_{\sim}\right.\right.$ $\mathrm{Lt})$ ] dengan $\mathrm{t}$ indikator minyak goreng pada $30.15^{\circ} \mathrm{C}$

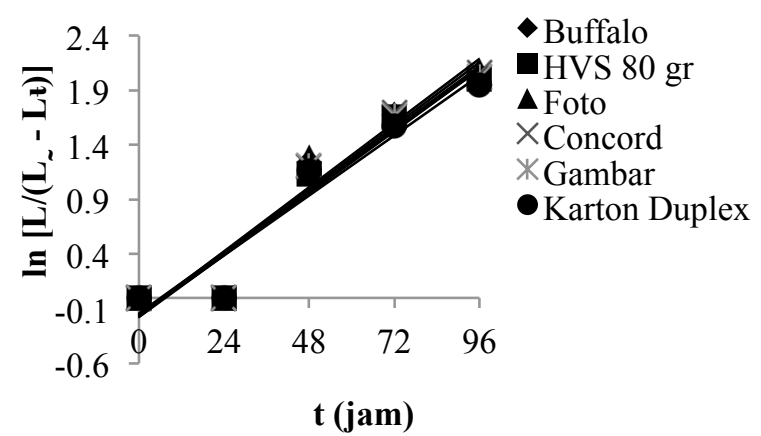

Gambar 14 Grafik hubungan antara $\ln \left[\mathrm{L} /\left(\mathrm{L}_{\sim}\right.\right.$ $\mathrm{Lt})$ ] dengan $\mathrm{t}$ indikator oli $\mathrm{A}$ pada $30.15^{\circ} \mathrm{C}$ 


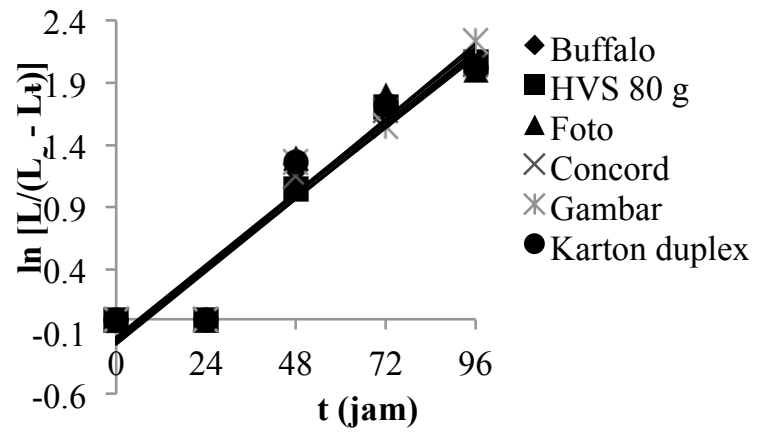

Gambar 15 Grafik hubungan antara $\ln \left[\mathrm{L} /\left(\mathrm{L}_{\sim}\right.\right.$ $\mathrm{Lt})$ ] dengan $\mathrm{t}$ indikator oli $\mathrm{B}$ pada $30.15^{\circ} \mathrm{C}$

Berdasarkan Gambar 13, Gambar 14 dan Gambar 15 dapat diketahui bahwa nilai konstanta laju setiap jenis medium terhadap indikator berbeda. Nilai konstanta laju resapan dari indikator minyak goreng, oli A dan oli B terhadap tiap jenis medium pada suhu $30.15^{\circ} \mathrm{C}$ secara lebih rinci dapat dilihat pada Tabel 3 .

Tabel 3 Nilai konstanta laju resapan pada indikator minyak goreng, oli A dan oli B pada suhu $30.15^{\circ} \mathrm{C}$

\begin{tabular}{llll}
\hline \multirow{2}{*}{$\begin{array}{l}\text { Jenis } \\
\text { Kertas }\end{array}$} & \multicolumn{3}{l}{ Konstanta Laju } \\
\cline { 2 - 4 } & $\begin{array}{l}\text { Minyak } \\
\text { Goreng }\end{array}$ & Oli A & Oli B \\
\hline $\begin{array}{l}\text { Buffalo } \\
\text { HVS } 80\end{array}$ & 0.0241 & 0.0233 & 0.0236 \\
gr & 0.0239 & 0.0236 & 0.0243 \\
Foto & 0.0240 & 0.0245 & 0.0242 \\
$\begin{array}{l}\text { Concord } \\
\text { Gambar }\end{array}$ & 0.0214 & 0.0242 & 0.0241 \\
$\begin{array}{l}\text { Karton } \\
\text { Duplex }\end{array}$ & 0.0242 & 0.0238 & 0.0251 \\
\hline
\end{tabular}

Densitas zat cair akan berkurang nilainya secara linier jika terjadi kenaikan suhu. Selain itu suhu yang tinggi juga akan menurunkan indeks kekentalan dari cairan. Dengan semakin rendah viskositas minyak goreng, maka akan semakin besar kemampuan alirnya pada medium tersebut. Hubungan antara $\ln \left[\mathrm{L} /\left(\mathrm{L}_{\sim}-\mathrm{L}_{\mathrm{t}}\right)\right]$ dengan $\mathrm{t}$ indikator minyak goreng $\left(50^{\circ} \mathrm{C}\right)$, indikator oli $\mathrm{A}\left(5^{\circ} \mathrm{C}\right)$, dan indikator oli $\mathrm{B}\left(5^{\circ} \mathrm{C}\right)$ dapat dilihat pada Gambar 16 , Gambar 17 dan Gambar 18.

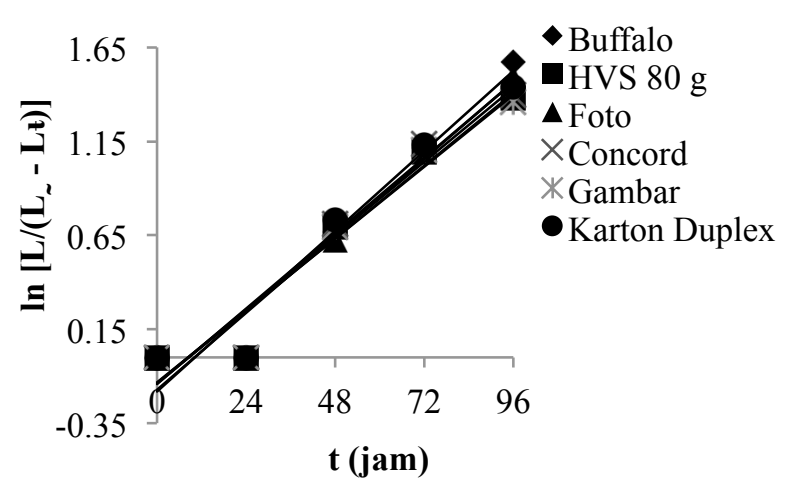

Gambar 16 Grafik hubungan antara $\ln \left[\mathrm{L} /\left(\mathrm{L}_{\sim}-\mathrm{Lt}\right)\right]$ dengan $\mathrm{t}$ indikator minyak goreng pada $50^{\circ} \mathrm{C}$

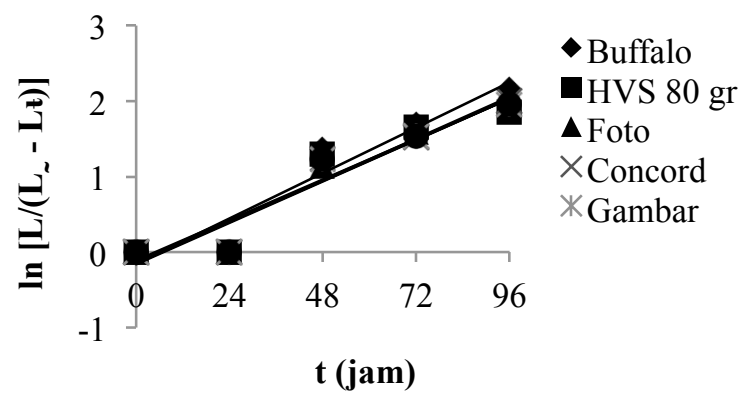

Gambar 17 Grafik hubungan antara $\ln \left[\mathrm{L} /\left(\mathrm{L}_{\sim}\right.\right.$ $\mathrm{Lt})$ ] dengan $\mathrm{t}$ indikator oli $\mathrm{A}$ pada $5^{\circ} \mathrm{C}$

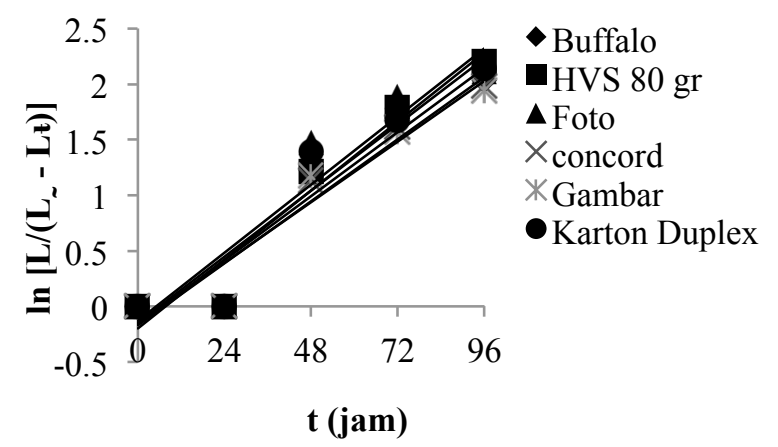

Gambar 18 Grafik hubungan antara $\ln \left[\mathrm{L} /\left(\mathrm{L}_{\sim}\right.\right.$ $\mathrm{Lt})$ ] dengan $\mathrm{t}$ indikator oli $\mathrm{B}$ pada $5^{\circ} \mathrm{C}$

Berdasarkan Gambar 16, Gambar 17, dan Gambar 18 menunjukkan bahwa nilai slope dari plot hubungan antara $\ln \left[\mathrm{L} /\left(\mathrm{L}_{\sim}-\mathrm{Lt}_{\mathrm{t}}\right)\right]$ dengan $\mathrm{t}$ berbeda. Nilai konstanta laju resapan dari indikator minyak goreng $\left(50^{\circ} \mathrm{C}\right)$, oli $\mathrm{A}\left(5^{\circ} \mathrm{C}\right)$ dan oli $\mathrm{B}\left(5^{\circ} \mathrm{C}\right)$ terhadap tiap jenis medium dilihat pada Tabel 4 .

Tabel 4 Nilai konstanta laju resapan pada indikator minyak goreng $\left(50^{\circ} \mathrm{C}\right)$, oli $\mathrm{A}\left(5^{\circ} \mathrm{C}\right)$ dan oli

\begin{tabular}{|c|c|c|c|}
\hline \multirow[b]{2}{*}{$\begin{array}{l}\text { Jenis } \\
\text { Kertas }\end{array}$} & \multicolumn{3}{|c|}{ Jenis Indikator } \\
\hline & $\begin{array}{l}\text { Minyak } \\
\text { Goreng } \\
\left(50^{\circ} \mathrm{C}\right)\end{array}$ & $\begin{array}{l}\text { Oli A } \\
\left(5^{\circ} \mathrm{C}\right)\end{array}$ & $\begin{array}{l}\text { Oli B } \\
\left(5^{\circ} \mathrm{C}\right)\end{array}$ \\
\hline Buffalo & 0.0178 & 0.0250 & 0.0240 \\
\hline
\end{tabular}




\begin{tabular}{llll} 
Concord & 0.0164 & 0.0230 & 0.0232 \\
Gambar & 0.0159 & 0.0227 & 0.0227 \\
Karton & 0.0167 & 0.0220 & 0.0248 \\
Duplex & & & \\
\hline
\end{tabular}

Pada suhu $5^{\circ} \mathrm{C}$ indikator oli mengalami penurunan panjang peresapan. Oli yang disimpan pada suhu rendah menjadi semakin kental. Viskositas yang tinggi dipengaruhi adanya penyusutan materi dan mempersempit jarak antar molekulnya. Jarak antar molekul yang lebih sempit tersebut akan meningkatkan viskositas oli dan kemampuan laju alirnya akan menurun juga. Panjang peresapan sesuai dengan pembuatan label cerdas karena ketersediaan tempat penyimpanan dalam lemari es yang tidak terlalu besar membuat label cerdas yang diaplikasikan menjadi lebih fleksibel dan praktis. Hubungan nilai $\ln \mathrm{k}$ terhadap 1/T dapat dilihat pada Gambar 19, Gambar 20, dan Gambar 21.

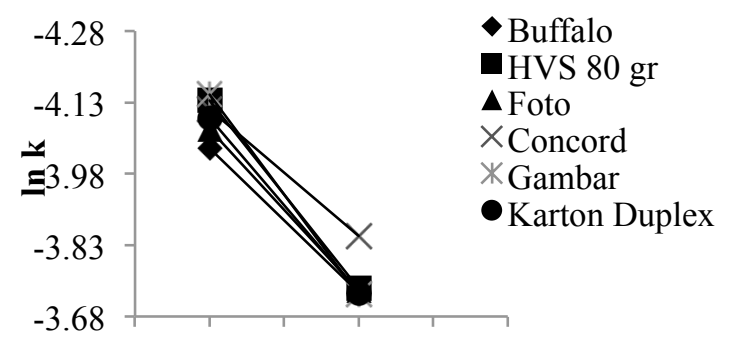

3.003 .103 .203 .303 .403 .50

$1 / \mathrm{T} / 10^{\wedge}-3$

Gambar 19 Grafik hubungan antara ln k dengan $1 / \mathrm{T}$ indikator minyak goreng

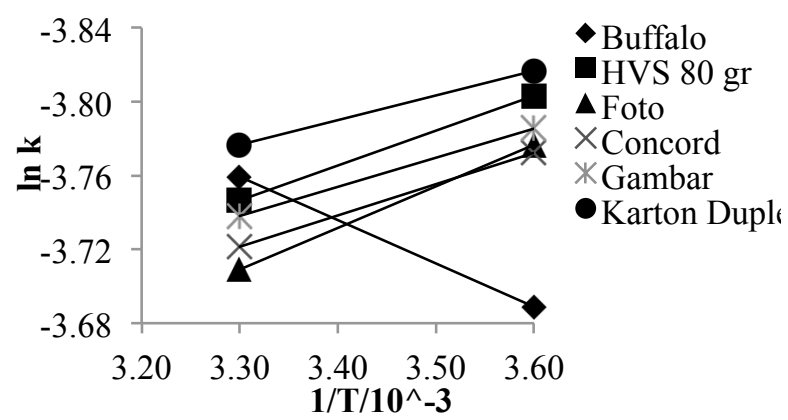

Gambar 20 Grafik hubungan antara ln k dengan $1 / \mathrm{T}$ indikator oli $\mathrm{A}$

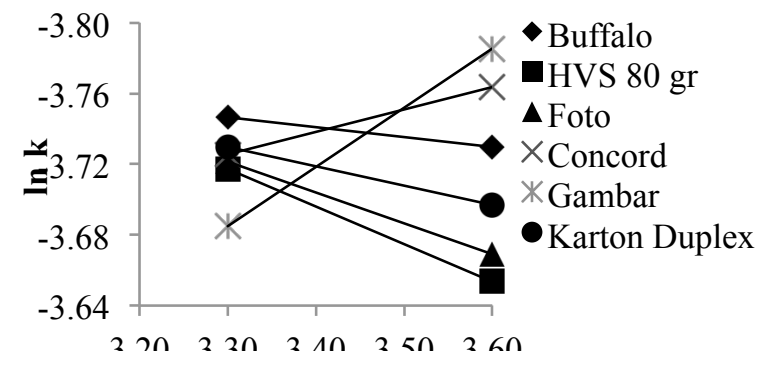

Gambar 21 Grafik hubungan antara ln k dengan $1 / \mathrm{T}$ indikator oli $\mathrm{B}$

Berdasarkan Gambar 19, Gambar 20, dan Gambar 21 grafik hubungan $\ln \mathrm{k}$ dengan 1/T menunjukkan adanya perbedaan slope. Indikator minyak goreng pada semua jenis medium menunjukkan nilai slope negatif. Pada indikator oli A, slope pada grafik secara garis besar bernilai positif kecuali pada kertas buffalo, sedangkan pada indikator oli B nilai slope nya bervariasi. Kertas concord dan kertas gambar mempunyai slope yang bernilai positif sedangkan kertas lain seperti buffalo, foto, HVS $80 \mathrm{~g}$, dan karton duplex mempunyai slope yang bernilai negatif. Nilai energi aktivasi (Ea) setiap indikator terhadap masing-masing medium dapat dilihat pada Tabel 5.

Tabel 5 Nilai energi aktivasi (Ea)

\begin{tabular}{|c|c|c|}
\hline Jenis Zat Cair & Jenis Kertas & $\operatorname{Ea}(J / \mathrm{mol})$ \\
\hline \multirow{12}{*}{ Minyak Goreng } & Buffalo & - \\
\hline & & 132002.936 \\
\hline & HVS $80 \mathrm{~g}$ & - \\
\hline & & 172106.323 \\
\hline & Foto & - \\
\hline & & 147669.839 \\
\hline & Concord & - \\
\hline & & 115929.788 \\
\hline & Gambar & - \\
\hline & & 182986.608 \\
\hline & Karton Duplex & - \\
\hline & & 159795.352 \\
\hline \multirow{6}{*}{ Oli A } & Buffalo & -1961.938 \\
\hline & HVS $80 \mathrm{~g}$ & 1578.496 \\
\hline & Foto & 1881.541 \\
\hline & Concord & 1416.872 \\
\hline & Gambar & 1318.351 \\
\hline & Karton Duplex & 1116.986 \\
\hline \multirow{6}{*}{ Oli B } & Buffalo & -468.236 \\
\hline & HVS $80 \mathrm{~g}$ & -1776.536 \\
\hline & Foto & -1457.777 \\
\hline & Concord & 1060.284 \\
\hline & Gambar & 1279.275 \\
\hline & Karton Duplex & -913.542 \\
\hline
\end{tabular}

Energi aktivasi merupakan energi minimum setiap indikator untuk dapat meresap pada medium selama 96 jam penyimpanan. Energi aktivasi pada semua jenis medium dengan indikator minyak goreng bernilai negatif. Indikator oli A benilai positif pada semua jenis medium kecuali kertas buffalo. Sedangkan oli B bernilai positif pada kertas gambar dan concord dan bernilai negatif 
indikator membutuhkan energi minimum untuk melakukan peresapan pada kertas, sedangkan bernilai negatif jika selama penyimpanan indikator tidak membutuhkan energi melainkan melepas energi. Energi aktivasi dapat menurun jika terjadi kenaikan suhu karena peningkatan suhu. Oli A dan oli $\mathrm{B}$ juga mempunyai energi aktivasi yang bernilai negatif, tetapi tidak pada semua jenis kertas. Adanya penurunan energi aktivasi hingga bernilai negatif tersebut bisa terjadi karena ketidaksesuaian antara indikator dengan sifat karakteristik medium.

Hubungan energi aktivasi dengan laju peresapan berbanding terbalik. Semakin besar energi aktivasi maka laju peresapannya semakin lambat. Karena energi minimum yang dibutuhkan indikator untuk meresap pada medium semakin besar. Pada pembuatan label cerdas ditentukan jenis medium dengan indikator yang mempunyai energi aktivasi yang tinggi agar indikator tersebut mempunyai laju peresapan yang rendah. Berdasarkan kondisi tersebut maka indikator yang paling baik untuk pembuatan label cerdas adalah oli A dengan urutan nilai energi aktivasi pada medium dari yang rendah sampai yang tinggi yaitu buffalo, karton duplex, gambar, concord, HVS $80 \mathrm{~g}$ dan foto.

Pada penelitian ini dilakukan identifikasi indikator dari zat cair yang berbeda viskositas dengan pemilihan zat cair yang sesuai yaitu jenis zat cair viskositas tinggi. Selain itu dari kelima jenis kertas dan satu jenis karton yang digunakan dalam identifikasi medium, dapat ditentukan jenis medium mana yang sesuai untuk pembuatan label cerdas berdasarkan panjang peresapan dan energi aktivasinya. Ada beberapa jenis zat cair lain yang memiliki viskositas yang tinggi secara alami. Kertas atau karton yang diidentifikasi sebagai medium hanya sebagian jenis kertas atau karton yang diproduksi dan beredar di pasaran. Terdapat jenis kertas atau karton lain yang dapat diidentifikasi sebagai medium.

\section{PENUTUP}

\section{A. Simpulan}

Gramatur kertas atau karton terendah sampai tertinggi yaitu kertas HVS $80 \mathrm{~g}$ gambar, buffalo, concord, foto dan karton duplex. Sedangkan rapat massa kertas atau karton terendah sampai tertinggi yaitu karton duplex, concord, buffalo, gambar, HVS $80 \mathrm{~g}$ dan foto. Nilai densitas dan viskositas ketiga indikator berbeda. Densitas dan viskositas dipengaruhi oleh suhu. Adaya peningkatan suhu menyebabkan nilai densitas dan viskositas menurun, begitu pula sebaliknya. Densitas tertinggi dan terendah ketiga indikator yaitu pada suhu $25^{\circ} \mathrm{C}$ dan $50^{\circ} \mathrm{C}$, sedangkan indikator viskositas tinggi pada suhu $40^{\circ} \mathrm{C}$ yaitu $\mathrm{Oli}$ A, oli B dan minyak goreng.

Suhu sangat berpengaruh pada daya resap indikator pada medium. Semakin rendah suhu menyebabkan daya resap indikatorr semakin rendah pula, dan sebaliknya. Indikator dan medium yang sesuai dapat ditentukan dari nilai tetapan laju serapan dan energi aktivasi. Berdasarkan nilai energi aktivasi, maka jenis indikator yang paling sesuai yaitu oli A dengan nilai energi aktivasi paling tinggi dari indikator yang lain. Minyak goreng dan oli B mempunyai energi aktivasi negatif. Nilai negatif menunjukkan tidak ada penghalang yang menghambat aliran indikator pada medium sehingga daya serapnya tinggi dan tidak sesuai dengan label cerdas yang akan dibuat dengan indikator yang mempunyai daya resap rendah. Dengan demikian nilai energi aktivasi pada medium dari yang rendah sampai yang tinggi yaitu buffalo, karton duplex, gambar, concord, HVS $80 \mathrm{~g}$ dan foto.

\section{B. Saran}

Indikator minyak goreng tidak dapat digunakan untuk indikator label cerdas karena mempunyai titik beku yang lebih tinggi dibandingkan suhu penyimpanan lemari es. Oleh karena itu, perlu dilakukan penelitian lebih lanjut mengenai zat cair lain yang mempunyai viskositas lebih tinggi dari oli agar daya serapnya rendah. Selain itu juga perlu dilakukan penelitian lebih lanjut mengenai jenis kertas atau karton lain yang dapat digunakan sebagai medium pembuatan label cerdas. Dengan adanya jenis kertas atau karton dan zat cair lain untuk pembuatan label cerdas, maka dapat diketahui jenis kertas atau karton dan zat cair yang paling sesuai untuk menghasilkan label cerdas dengan aplikasi penyimpanan yang lebih maksimal.

\section{UCAPAN TERIMA KASIH}

Penulis mengucapkan terima kasih kepada Dr. Endang Warsiki, S.TP., M.Si atas bimbingan dan arahannya selama penulis menyelesaikan skripsi dan penelitian ini. Penulis juga menyampaikan terima kasih kepada Departemen Teknologi Industri Pertanian IPB yang telah memberikan bantuan dana penelitian. Terima kasih dan penghargaan terutama juga diperuntukkan kepada kedua orang tua, keluarga, dan sahabat atas doa dan dukungan yang diberikan sehingga penulis dapat menyelesaikan penelitian dengan baik.

\section{DAFTAR PUSTAKA}

[BSN] Badan Standarisasi Nasional. 2006. Biodiesel. Jakarta : Standar Nasional Indonesia.

「BSN] Badan Standarisasi Nasional. 2008. Kertas 
Adrimarsya. 2012. Difusi Dan Osmosis [Internet]. [diunduh 2014 Jan 12]. Tersedia pada : http://Adrimarsya.wordpress.com/2012/12 /05/difusi-dan-osmosis/.

Casey JP. 1961. Pulp and Paper, vol.II Second Ed. New York : International Publisher.

Coe JS. 1971. Chemical Equilibrium. An Introduction, London : Methuen Educational. p. 1-7.

Cuah TG, Ling HL, Chin NL, Choong TSY, Fakhru'l-Razi A. 2008. Effect temperatures on rheological behaviour of dragon fruit (hylocereus sp). J Food Eng 4(7): 1-30.

Kanoni. 1999. Hand Out Pengetahuan Bahan (Viskositas). TPHP UGM. Yogyakarta.Utomo, J.S. dan S.S. Antarlina. 2002. Tepung Instant Ubi Jalar untuk Pembuatan Roti Tawar. Majalah Pangan No: 38/XI/Jan/2002. hlm: 28-34.

McCabe WL, Smith JC, Harriot P. 1999.Unit Operasi Teknik Kimia, Edisi 4. Ir. E. Jasjfi, M.Sc, penerjemah. Jakarta (ID): Erlangga. Terjemahan dari Unit Operations of Chemical Engineering, Fourth Edition.

Noureddini H, Teoh BC, Clements LD. 1992. Densities of vegetabel oils and fatty acids. J Am Oil Chem Soc 69(12): 1184-1188.

Nugroho SR, Sunarno H. 2012. Identifikasi Fisis Viskositas Oli Mesin Kendaraan Bermotor terhadap Fungsi Suhu dengan Menggunakan Laser Helium Neon. Jurnal Sains dan Seni. hlm: 1-5

Robertson G. 2006. Food Packaging Principles and Practices. Ed ke-2. Boca Raton, Fla: Taylor \& Francis.

Sinuhaji P. 2010. Interaksi Serat Limbah Industri Pulp Dengan Serat Nanas, Pisang Dan Rami Pada Pembuatan Karton [disertasi]. Medan : Universitas Sumatra Utara

Soedarmo H. 2008. Panduan Praktis Merawat \& Memperbaiki Sepeda Motor. Jakarta : Gedium Pustaka Utama.

Taoukis PS, Labuza TP. 1989. Applicability of time temperature indicators as shelf-life monitors of food products. Di dalam Joseph K, Paul B, editor. Journal of Food Science, 54, 783-788.

Vaitilingom G, Liennard A. 1997. Various Vegetables Oils as Fuel for diesel and Burners : J. cuercasi Particularities. Hlm.. 98-109 dalam G.M. Gubitz, M. Mittelbach dan M. Trabi (ed), Biofuels and Industry Product from Jatropha curcas, , Austria : Dbv - Verlag Fur die Technische Universitat Graz 
